\title{
The Global Environmental Justice Atlas (EJAtlas): ecological distribution conflicts as forces for sustainability
}

\author{
Leah Temper $^{1} \cdot$ Federico Demaria $^{1,2,3}(\mathbb{0}) \cdot$ Arnim Scheidel $^{1} \cdot$ Daniela Del Bene $^{1,2} \cdot$ Joan Martinez-Alier $^{1}$
}

Received: 30 March 2018 / Accepted: 10 April 2018 / Published online: 20 April 2018

(c) Springer Japan KK, part of Springer Nature 2018

\section{Introduction}

The environmental movement may be "the most comprehensive and influential movement of our time" (Castells 1997: 67), representing for the 'post-industrial' age what the workers' movement was for the industrial period. Yet while strike statistics have been collected for many countries since the late nineteenth century (van der Velden 2007), ${ }^{1}$ until the present no administrative body tracks the occurrence and frequency of mobilizations or protests related to environmental issues at the global scale, in the way that the World Labour Organization tracks the occurrence of strike action. ${ }^{2}$ Thus until the present it has been impossible to properly document the prevalence and incidence of contentious activity related to environmental issues or to track the ebb and flow of protest activity. Such an exercise is necessary because if the twentieth century has been the one of workers struggles, the twenty-first century could well be the one of environmentalists. This Special Feature presents the results from such an exercise-The Global Atlas of Environmental Justicea unique global inventory of cases of socio-environmental conflicts built through a collaborative process between academics and activist groups which includes both qualitative and quantitative data on thousands of conflictive projects as well as on the social response.

Handled by Osamu Saito, UNU-Institute for the Advanced Study of Sustainability, Japan.

Federico Demaria

federico.demaria@uab.cat

1 Institute of Environmental Science and Technology (ICTA), Universitat Autònoma de Barcelona, Barcelona, Spain

2 Research \& Degrowth, Barcelona, Spain

3 Facultad Latinoamericana de Ciencias Sociales (FLACSO), Buenos Aires, Argentina
This Special Feature applies the lenses of political ecology and ecological economics to unpack and understand these socio-environmental conflicts, otherwise known as 'ecological distribution conflicts', (hereafter EDCs, Martinez-Alier 1995, 2002). The contributions in this special feature explore the why, what, how and who of these contentious processes within a new comparative political ecology.

The articles in this special issue underline the need for a politicization of socio-environmental debates, whereby political refers to the struggle over the kinds of worlds the people want to create and the types of ecologies they want to live in. We put the focus on who gains and who loses in ecological processes arguing that these issues need to be at the center of sustainability science. Secondly, we demonstrate how environmental justice groups and movements coming out of those conflicts play a fundamental role in redefining and promoting sustainability. We contend that protests are not disruptions to smooth governance that need to be managed and resolved, but that they express grievances as well as aspirations and demands and in this way may serve as potent forces that can lead to the transformation towards sustainability of our economies, societies and ecologies.

\section{This special feature}

The articles in this collection contribute to a core question of sustainability science-why and through what political, social and economic processes some are denied the right to a safe environment, and how to support the necessary social and political transformation to enact environmental justice. While there exists broad consensus about the existence of the sustainability crisis (World Economic Forum

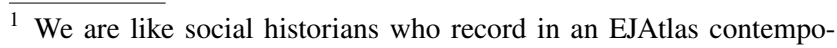
rary socio-environmental struggles as others recorded peasant uprisings or labor union strikes around the world http://www.laborbooks .com/Item/strikewrld.

${ }^{2}$ See http://laborsta.ilo.org/).
} 
2018), everything else is a source of dispute. Scholars debate among market-based solutions, technological innovations and top-down policies. Yet the mainstream techno-managerial solutions proposed tend to overlook relations of power and issues of distribution, and to dismiss or minimize the import of political dissent. There are calls for a transformation towards sustainability, yet as Swyngedouw (2011: 76) points out "the techno-managerial eco-consensus maintains we have to change radically, but within the contours of the existing state of the situation [...] so that nothing really has to change!". Sustainability discourses often remain stuck in what is called a post-political space: a political formation that forecloses the political, the legitimacy of dissenting voices and positions. Such an approach risks falling into the trap of "everything needs to change, so everything can stay the same"

At the same time communities around the world are organizing and coming out to the streets en masse to oppose or problematize the imposition of "development" projects, landfills, mines and even large renewable projects and climate fixes. In many places, they put their lives on the line to do so, as reports on environmental activists killed attest to (Global Witness reports almost 200 in $2017^{4}$ ). See also Global Witness 2016). This raises pressing questions of utmost relevance for sustainability studies. What are the reasons for the vast number of 'ecological distribution conflicts'? What are these contentious movements claiming against and for? And what they can tell the world about our (un)sustainability crisis?

The included articles touch on a range of countries and regions (China, Spain, Central America, Venezuela, Sri Lanka, the Balkans, Andean countries and Brazil) and themes (e.g., oil extraction, wind mills, dams, cement kilns, waste incinerators, etc.). What they share is that they all employ a comparative perspective, examining multiple cases of ecological conflicts as entered into the EJAtlas database, with the intention to foster a comparative (and possibly also statistical) political ecology. We argue that such an approach can enrich environmental justice (hereafter EJ) studies in particular, and sustainability science more in general, by going beyond the isolated case study approach to offer a wider systematic evidence-based enquiry into the politics, power relations and socio-metabolic processes surrounding EJ struggles locally and globally. Taken together, the articles demonstrate both the differences and the commonalities in how place-based struggles for environmental justice

\footnotetext{
3 This is the most famous line of the novel The Leopard by Giuseppe Tomasi di Lampedusa (1963).

4 https://www.theguardian.com/environment/2018/feb/02/almos t-four-environmental-defenders-a-week-killed-in-2017?CMP $=$ share _btn_tw.
}

manifest, evolve and make an impact across locations (political ecology); and how these are shaped by material conditions, by the changes in the social metabolism, ${ }^{5}$ the commodities being produced and the political economy of their production (ecological economics).

In this introductory paper, we draw the contours of this research agenda in relation to the contents of the special feature. First we introduce the theoretical underpinnings of ecological distribution conflicts and social metabolism, and then the environmental justice atlas mapping process, outlining its aims, methodology and development of this tool for activism, advocacy and scientific knowledge production. Next, we discuss the contents of the papers included in this Special Feature. Finally, we conclude with a research and action agenda.

\section{Theoretical framework: ecological distribution conflicts (EDCs)}

An ecological distribution conflict can be defined as a collective action (such as a writing of petitions, demonstrations, blockades etc.), induced by existing or anticipated environmental pollution or damage to nature affecting communities, which has been caused or will be caused by increases or changes in the social metabolism. The objective is to stop or prevent environmental pollution or damage or to recoup the losses already produced through appeals to civil society, news media and public opinion (national and/or international), public administration (the courts, other government institutions) and business corporations.

The concept of 'ecological distribution conflict' stresses how beyond economic distribution struggles,${ }^{6}$ there exists struggles over ecological distribution (Martinez-Alier and O'Connor 1996). This includes unequal exposure to pollution due to unequal power, class, race and gender relations, and their intersectionality-contrary to what Ulrich Beck suggested (1992), smog is not democratic, nor is contaminated water, food, soil-as well as unequal access to land, energy, fuelwood, green spaces, etc. There are local as well as global ecological distribution conflicts.

Ecological conflicts can be seen as analogous to class conflicts, however, they rarely manifest through worker's strikes, and their demands are not for economic compensation or fairer working conditions. They lead to contentious

\footnotetext{
5 Social metabolism refers to the material and energy flows in the economy (Gerber and Scheidel 2018). See http://www.ejolt .org/2012/11/social-metabolism-and-accounting-tools/.

${ }^{6}$ For example, these would be those conflicts between capital and labor-profits vs. salaries-, or on prices between sellers and buyers of commodities, or on the interest rate to be paid by debtors to creditors.
} 
actions of movements aiming to halt unsustainable resource uses, often caused by the destructive force of capitalist production on environmental and human health, through a wide repertoire of forms of protest. Ecological conflicts represent an important and expanding field of study (e.g., MartinezAlier et al. 2010).

They often occur between the global South and the global North, i.e., communities in rural Peru affected by a Canadian or Chinese mining company, or residents in cities around the world affected by large scale construction expansion funded by global capital. However, there are also many local conflicts within a short commodity chain, e.g., on local sand and gravel extraction for a nearby cement factory (Martinez Alier 2002). From a socio-metabolic perspective one can classify EDCs through the stages of a commodity chain; conflicts can take place during the extraction of energy carriers or other materials, transportation and production of goods, or in the final disposal of waste.

We contend that conflicts are a response to the growth and changes in the social metabolism, i.e., the flows of energy and materials in the economy. This is the primary cause of ecological distribution conflicts. The industrial economy, in fact, is not circular, it is entropic (Georgescu-Roegen 1971). Materials are recycled only to a small extent. The global economy recycles less than $10 \%$ of materials; about $50 \%$ of processed materials are used to provide energy (basically fossil fuels) and are thus not available for recycling (Haas et al. 2015). Energy is not recycled and therefore there is a search for new sources at the commodity extraction frontiers, whether it is coal, oil, gas, wind, or hydro power. Also, it is the incessant search for metals and building materials, and biomass such as timber and fish which are extracted at rates quicker than their reproduction that necessarily create conflicts of dispossession and contamination (Demaria and D'Alisa 2013). Moreover, the disposal of such materials in dumpsites, incinerators or anywhere else without any treatment, is also a matter of conflicts. Excessive amounts of greenhouse gases are dumped into the atmosphere. The consequence of the fact that the economy is not circular but entropic is that many EDCs arise.

These conflicts bring value system contests into the open. For instance, if a river is polluted or a forest destroyed by open-cast mining, financial compensation may be a way out for the company responsible but other valuation languages (biodiversity, the "rights of nature", the livelihood of local populations, indigenous territorial rights, sacredness) will then be sacrificed. But often no amount of monetary compensation will prevent a conflict from taking place, simply because people hold non-monetary social values as well (Temper and Martinez Alier 2013, Demaria 2010). The language of economics (and of monetary cost-benefit analysis) is powerful but it is not always powerful enough. Ecological and economic distribution conflicts are not coterminous.
Economists claim that all externalities just need to be internalized in the price, but reality shows that not everything can have a price tag. The enclosed articles show many instances of value system contests in ecological distribution conflicts (Martinez-Alier and O'Connor 1996).

In the EJAtlas we are scratching the surface of this wave of rebellion for environmental justice. When the EDCs have successful outcomes, they contribute to Just Sustainabilities (Agyeman 2008) by degrowing the use of raw materials and the production of noxious waste (Akbulut et al. 2018, forthcoming). Ecological distribution conflicts are thus strong transformative forces for sustainability, thus the importance of looking at their politics and demands more closely and in depth [for an overview and conceptual framework, see Scheidel et al. (2018), this feature]. More resistance might mean less mining, less plunder of biomass and less fossil fuel extraction. How much carbon emissions have been avoided when protestors achieved to stop explorations? How many hectares of land are still cultivated by small farmers instead of being leased out to industrial farming, or covered by cement? This is the view from the grassroots, from the myriad environmental justice organizations (EJOs) around the world. Moreover, EJOs are not only oppositional movements, but also propositional and pro-active, as they oppose something for protecting a different way of producing, exchanging, living (Temper et al. 2018, this feature). A special feature in this Journal explored how degrowth promotes a social-ecological transformation by repoliticizing sustainability science (Asara et al. 2015). However, worldwide there are many alternatives to the hegemonic notion and practice of development that all together compose a pluriverse: 'a world where many worlds fit', as the Zapatista say (Demaria and Kothari 2017). Environmental justice movements are part and parcel of this collective search for an ecologically wise and socially just world.

\section{Methods: The Global Atlas of Environmental Justice (EJAtlas)}

The EJAtlas constitutes the largest existing inventory documenting ecological struggles from around the world. In 5 years, it has collected data on 2400 cases (as of March 2018) (Fig. 1). It is an ongoing project, with an average of one case added per day. It documents resistance to extractivism and to toxic pollution, territorial defense by peasants and indigenous communities against mines, dams, coercive conservation projects and deforestation, protests of urban and rural dwellers against mega-projects, military and energy infrastructure and gentrification as well as conflicts over waste disposal such as opposition to landfills, incinerators, also climate justice movements and opponents of false solutions such as geo-engineering. Those mobilizing do so due 


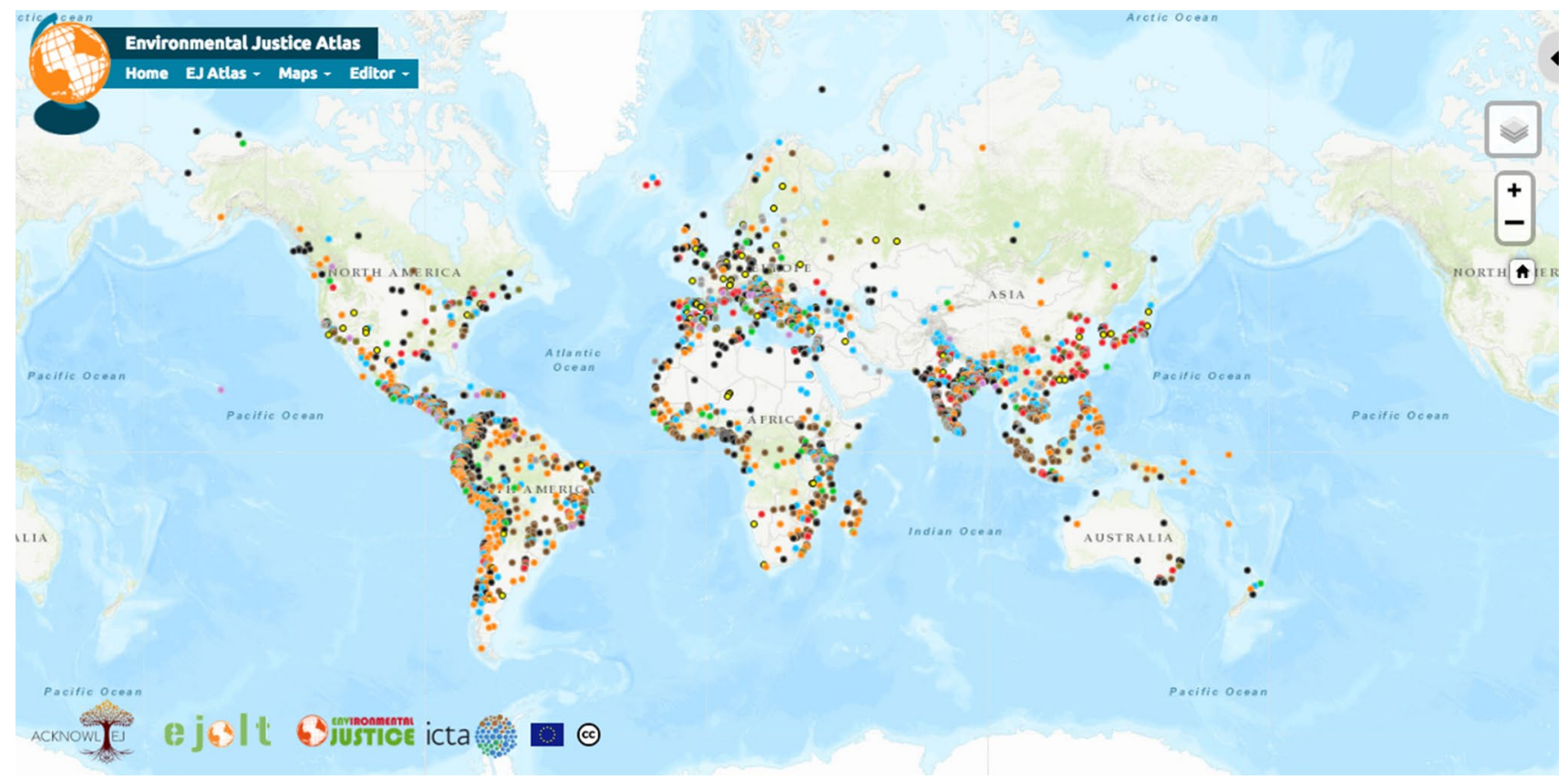

Fig. 1 The online platform of the EJAtlas. Each point represents one case study of a conflict (See http://ejatlas.org/)

to the destructive social, environmental and health impacts wrought by these projects, whereby the benefits flow elsewhere, often upwards, while the burdens are displaced onto the poorest, racialized, most vulnerable, discriminated and marginalized social groups and communities.

Data are gathered in database forms through a collaborative online platform, and are then revised and moderated before publication. The database allows country-analyses and also transversal thematic analyses as shown in the special feature. The sheer size of our database makes comparative studies possible on the actors in such conflicts and their forms of mobilization, the companies involved, the intensity of the conflicts including deaths of activists and other forms of violence, and the factors that lead to failure or success in achieving environmental justice.

Ecological distribution conflicts arise precisely when communities refuse to be polluted, to be contaminated, displaced and erased and decide to mobilize and rise up in social opposition. The EJAtlas captures their struggles, including writing letters and petitions to the authorities, popular assemblies, land or road occupations and blockades, strikes, street protests and parades, legislative initiatives, court cases and a myriad forms of civil disobedience. The outcomes of such conflicts are also diverse, as well as dynamic. As several articles in this collection outline, activists are often exposed to repression or co-optation (Navas et al. 2018, this feature; Del Bene et al. 2018, this feature), yet there are also significant victories at the local scale leading to projects being stopped; as well as at wider interlinked scales, where governments are forced to rethink development trajectories, retool processes of democratic consultation and respect indigenous claims for self-determination. In this special feature, we are especially concerned with how and when resistance leads to such processes of social transformation towards more sustainable futures.

The EJAtlas may be considered a contemporary environmental history from below. As founder-directors and contributors ${ }^{7}$ of the project we see our role as chroniclers of a global movement for environmental justice leading to social transformation in process, of a history of struggle that is actively creating new worlds and new possibilities. This special feature, drawing from the raison d'être of the EJAtlas, argues that the organization and resistance of those taken to be powerless hold greater promise for a new politics of sustainability than the failed or ineffectual top-down initiatives championed by state leaders and international organizations at international gatherings such as the COPs. The EJAtlas takes seriously the belief that the peasants, the polluted, the workers, the indigenous are not a minority, and are neither simply victims nor spectators but that they constitute the

\footnotetext{
7 The EJAtlas is housed at the ICTA, Universitat Autonoma de Barcelona. It was founded and is co-directed by Leah Temper and Joan Martinez-Alier, and is coordinated by Daniela Del Bene. It is at present financed by the ERC Advanced Grant 2016-21 to Joan MartinezAlier for the project EnvJustice (A global movement for environmental justice) and by the Acknowl-EJ project (Academic-Activist Co-Produced Knowledge for Environmental Justice) 2016-19 funded by the ISSC to Leah Temper and co-led by Ashish Kothari. Federico Demaria is the coordinator of Envjustice, and has coordinated this special feature. Arnim Scheidel is a member of EnvJustice.
} 
driving force behind the necessary sustainability transformation. The goal of the EJAtlas is thus to document, understand and analyze the political outcomes that emerge or that may emerge from such histories of social conflict (Temper et al. 2015; Temper and Martinez-Alier 2017).

\section{Origins and aims}

The EJAtlas is named after the discourse and movement that emerged in the United States in the 1980s focusing on the unfair distribution of environmental benefits and burdens to "people of color". The "environmental justice" movement developed concepts such as "environmental racism", "popular epidemiology", "sacrifice zones" (Bullard 1990, 1993). In 1991, it proclaimed the Principles of Environmental Justice which are indeed relevant much beyond the United States. They emphasized disproportionate environmental damage made to "people of color", against "minorities". It should be said that in a global context, such minorities are the majority, showing the importance of Decoloniality as a new perspective and a movement from the South (Grosfoguel 2004).

The EJAtlas was informed, based on and co-designed together with global environmental justice organizations; many of which had been building their own repositories of knowledge on such ecological conflicts over the past 30 years in some cases. These include the Observatory of mining conflicts of Latin America (OCMAL), Oilwatch, World Rainforest Movement, FIOCRUZ and the Brazilian network of Environmental Justice (Da Rocha et al. 2017, this feature); GAIA (alliance against incineration of waste, Herrero and Vilella, this feature); and the Centro di Documentazione sui Conflitti Ambientali (CDCA), as well as other sources (as in Latorre et al. 2015 for Ecuador). These databases represented invaluable empirical evidence on the impacts of new forms of extractivism based on activist production of knowledge created through conflict, however they were and are limited by geographic or thematic boundaries.

Within the aegis of the EJOLT project (Environmental Justice Organizations Liabilities and Trade, 2011-2015) the EJAtlas was thus conceived as a way to integrate this activist knowledge into a global platform that could serve as a tool for activism, advocacy, research and public education. The atlas thus aimed to systematize and to distill within a concise and codified structure these stories of struggle, acknowledging the limited range of spatial and narrative illustrations to express the struggles, desires and values of the communities within such a GIS format (for a discussion of co-design and co-production of knowledge, see Temper and Del Bene 2016). At the same time, the EJAtlas aimed to transcend the "case study based approach" of most political ecology and EJ literature through the creation of a tool that could help identify patterns, relationships among multiple cases and actors and describe how such conflicts are shaped by the larger political economy.

The EJAtlas is a hybrid research project in that beyond the scientific aims, it hopes to: (1) serve as a tool for activism and advocacy; (2) help visibilize and denounce cases of environmental injustice; (3) encourage dialogue and the interchange of experiences, ideas, data, and strategies of actions; (4) help networking between movements and strengthen strategies of international articulation on EJ, and (5) contribute to new processes of knowledge creation within an EJ perspective (Temper et al. 2015). It represents a new form of research based on knowledge co-production that valorizes the knowledge created through processes of struggle.

At the same time, we can say that a further aim of the EJAtlas is to support and contribute to the cohesiveness and self-awareness of an emerging globalizing movement for environmental justice (Martinez-Alier et al. 2016). An exercise that falls under what the historian Vijay Prashad describes as a socialist writing project ${ }^{8}$ —one intended to produce a confident community of struggle and to empower opposition to the status quo through the sharing of narratives that highlight the agency of those struggling to create better worlds.

\section{Methodology and data collection}

The conflicts analyzed in most of the articles in this special feature were reported by academic researchers and also by various environmental NGOs, social activists, and journalists, and collected in the EJAtlas. The unit of analysis in the EJAtlas is a well-documented project-based campaign or place-based struggle related to claims against perceived negative social or environmental impacts which sometimes results in influential national protest-events or broader campaigns. These contestations are made visible through press reports and court cases, campaigning, petitions, meetings, demonstrations, boycotts, strikes, threats, civil disobedience, collective violence, and other action forms.

Cases to be entered into the atlas are selected due to their significance as either qualified (1) according to the opinion of environmental activists and organizations in the country, region of thematic area; ${ }^{9}$ (2) by media coverage; and (3) due to the size of the project, amount of investment, scale of the impact and intensity of the conflict. The intention is to document the most significant cases per country and per conflict type. The EJAtlas can be described as a large, purposive,

\footnotetext{
${ }^{8}$ See this interview to Vijay Prashad by Mark Nowak titled "Writing While Socialist" at Boston Review: A political and literary review (26/09/217). Available at: http://bostonreview.net/global-justice/vijay -prashad-mark-nowak-writing-while-socialist.

9 See Grafton et al (2015), for an example of such a methodology for
} the US. 
expert-elicited sample of recent, visible, previously reported ecological distribution conflicts from around the world, with still uneven geographical coverage.

Information about the conflict cases comes from public institutions, local activist groups, academics, companies' websites, and blogs, magazines and newspapers. Sources are quoted in the database forms, which are publicly available (http://www.ejatlas.org). Cases are entered via an online platform onto a 5-6-page codified form which contains the name and geo-location of the conflict, a general description, and coded variables on the commodities in question, the environmental, health and socio-economic impacts, the social actors and their forms of mobilization, and the outcomes of the conflicts (available by clicking on the conflict sheet). These data sheets also have a section on sources and references, and links to photographs of protagonists and their banners, slogans and songs, and videos illustrating the cultural expressions environmental conflicts. Following data entry on the online form the cases are reviewed and moderated by the atlas editorial team based at the ICTAUAB. (More details on the methodology of the EJAtlas are in Temper et al. 2015.)

The atlas demonstrates how pollution and destructive environmental impacts are distributed unequally not only amongst countries but that globally those most impacted by such projects continue to be indigenous peoples and poor communities. For example, indigenous populations constitute $5 \%$ of the global population and $15 \%$ of the extremely poor (at least in monetary terms), according to the World Bank, ${ }^{10}$ and yet, they are affected in no less than $40 \%$ of the cases documented in the atlas. Further, as Del Bene et al. (2018, this feature) and Navas et al. (2018, this feature) demonstrate, the cases where they do figure tend to include greater repression, criminalization and deaths. Similar to the ground-breaking studies that established the disproportionate exposure of black and minority communities in the United States (UCC 1987), this points to systematic global environmental discrimination against indigenous communities, who are stewards and protectors of 80 percent of the planet's biodiversity (Warner 2015), yet are being dispossessed, displaced and exterminated for defending their territories.

Beyond the violence, there are also stories that inspire. Numerous cases of projects on hold, stopped or redesigned. Twenty per cent of the projects documented have been

\footnotetext{
10 "Indigenous Peoples are culturally distinct societies and communities. Although they make up 5\% of the global population, they account for about $15 \%$ of the extreme poor." See the Indigenous People Policy by the World Bank. Available at: http://www.worldbank. org/en/topic/indigenouspeoples.
}

stopped altogether. ${ }^{11}$ This hints to the successes and also the difficulties of the environmental justice movements in contributing to improve the sustainability of the economy. Along these lines, in the next section we provide a preview of the results presented by the articles in this special feature.

\section{The contributions to this special feature}

This special feature brings together selected papers presented at the Political Ecology ENTITLE conference called 'Undisciplined Environments' in Stockholm, March $2016^{12}$ along with others. Each paper engages with the EJAtlas, from a variety of different locational, conceptual, theoretical approaches. They include contributions from a wide range of countries and regions: Sri Lanka, the former socialist countries of South Eastern Europe, Central America, Venezuela and the Andean countries, Spain, Brazil and China, covering over 742 individual conflict case studies (see Fig. 2). Some focus on a single issue (like waste incinerators in China or cement kilns in Spain), while other on diverse activities within a defined territorial space. The special feature contains also two thematic transversal articles, comparing the same issue (hydropower; wind mills) across conflicts in different countries, a general overview conceptual article, and one about resistance-centered perspective on transformation.

According to the different ways authors use the EJAtlas, we have classified and ordered the contributions as follow:

1. Overview and conceptual framework (Scheidel et al. 2018, this feature);

2. Transversal articles: worldwide conflicts related to wind energy (Avila 2018, this feature) and hydropower (Del Bene et al. 2018, this feature);

3. Regions: Andean countries (Perez-Rincón et al. 2017, this feature), Central America (Navas et al. 2018, this feature), ex-Yugoslavia (Špirić 2017, this feature);

4. Countries: Venezuela (Teran-Mantovani 2018, this feature), Sri Lanka (Camisani 2018, this feature), Brazil (Da Rocha et al. 2017, this feature);

5. Single issues in one country: cement kilns in Spain (Herrero and Vilella 2018, this feature) and waste incineration in China (Johnson et al. 2018, this feature);

6. Resistance-centered perspective on transformation (Temper et al. 2018, this feature).

\footnotetext{
11 According to the Latin American Observatory of Mining Conflicts "There are U.S. \$ 30 billion worth of investments in mining that are at this moment paralyzed as a consequence of popular resistance to mining in Latin America" http://www.conflictosmineros.net/conte nidos/3-latinoamerica/14886-la-resistencia-a-lamineria-en-americalatina-tiene-paralizados-us-30-mil-millones.

$12 \mathrm{http} / / / \mathrm{www}$.politicalecology.eu/news/item/entitleconference.
} 




World Map
746 cases filtered

You can contribute to EJ Atlas and / or fill out our survey.
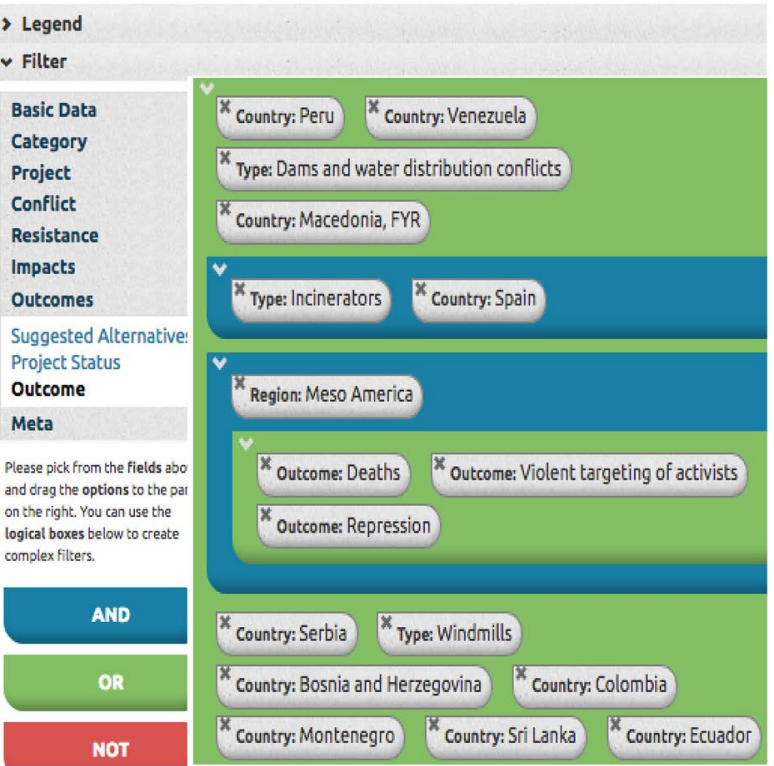

Fig. 2 The cases covered in this special feature as displayed using the EJATLAs filter tool (see ejatlas.org)

\section{Overview and conceptual framework}

The overview article by Scheidel et al. presents a conceptual framework that systematizes the thinking around the primary theses of the special issue-that ecological distribution conflicts arise from the growth and changes in the social metabolism, and that they can have an important role for sustainability, because they relentlessly bring to light conflicting values over the environment as well as unsustainable resource uses affecting people and the planet. The article traces the linkages between patterns of (unsustainable) social metabolism, the emergence of ecological distribution conflicts, and the rise of environmental justice movements, born out of such conflicts, which become key actors in politicizing such unsustainable resource uses, and ultimately can become potential important agents in sustainability transitions.

\section{Transversal articles: wind energy and hydropower}

Avila collects information and analyzes features of 20 wind energy conflicts from around the world building on her knowledge of such conflicts in the Isthmus of Tehuantepec in Mexico (Avila 2017). She looks at emerging discourses against wind power that are going beyond defense of landscape to challenge the ecological modernization paradigm that dominates in the low-carbon transition. Interesting confluences arise in some of the cases between an "environmentalism of the poor" against land grabbing by wind power companies and conservationist concerns about birdlife.

Del Bene et al. analyze a large sample of 220 hydropower related conflicts across the globe. The authors emphasize the need to integrate knowledge co-produced between academics and activists, in order to make visible those impacts of large-scale dam development that often remain unassessed: i.e., the forms of repression, criminalization and violence that protesters may face. They show that such impacts are more frequently found when indigenous groups are involved in the protests. Furthermore, they caution against equating renewable energy provision with sustainable energy provision and argue that the repression of the opposition against unwanted energy infrastructures serves not only to curb and silence specific protest actions, but to delegitimize and undermine differing understandings of sustainability, epistemologies, and world-views.

\section{Regions: Andean countries, Central America and ex-Yugoslavia}

The article by Perez-Rincón et al. argues that the patterns of ecological conflicts in the Andean countries can be explained by the structural shifts of the economies and the concomitant changes in their metabolic profiles. Since the 1990s, these countries went through a strong re-primarization 
process - the extraction of materials has multiplied by a factor of four while there has been a shift from agrarian extraction (biotic) to mineral extraction (abiotic) of metals and fossil fuels, mostly for export, intensifying environmental pressures and conflicts. The authors have been the main contributors to the EJAtlas from Colombia, and their sample includes 240 ecological distribution conflicts from Colombia, Ecuador, Peru and Bolivia.

Navas et al. comparative analysis of violence documented in the countries from Guatemala to Panama, is based on 95 cases of environmental conflicts recorded in the EJAtlas in Central America, added mostly by Navas herself in cooperation with local activists and experts. In discussing the many ways how violence against protesters and affected communities can manifest, Navas et al. show why it is necessary to discuss not only visible but also invisible forms of violence within environmental conflicts, and more broadly, sustainability studies. Their focus is not only on assassinations and open repression against activists (of which there are many cases) but also on the "slow murders" caused in some countries by the nematicide dibromochloropropane (DBCP) and the lack of redress for the men and women affected by illness. Theoretically, they propose the concept of multidimensional violence.

Špirić's paper takes a historical and comparative regional lens, examining the occurrence and characteristics of 74 ecological distribution conflicts and the evolution of environmental movements in five ex-Yugoslav countries: Bosnia and Herzegovina, Croatia, Macedonia, Montenegro, and Serbia, through three distinct phases in the region's history, i.e., the periods of Socialism (1945-1990), Transition (1991-2003), and EU accession (2004-present). Each of these historical periods are characterized by different socio-metabolic, political and institutional profiles. Špirić tracks the evolution of an increasing environmental consciousness, from demands for monetary compensation during socialist times in response to polluting state-owned industries and mines to movements in the current phase who "embrace broader questions about centralized power, commodification, crony capitalism, land ownership, water quality and other socioenvironmental issues," and struggles which now include for instance saving a local park from real estate development (EJAtlas 2014a).

\section{Countries: Venezuela, Sri Lanka and Brazil}

At the country level, Teran-Mantovani demonstrates for Venezuela how the specific metabolism associated with oil rents has led to the rise of a petro-state that has been able until the present to isolate the impact of ecological devastation related to fossil fuel extraction to a discrete area in the country and largely pacify resistance through the redistribution of oil rents in social welfare programs. He describes how the Bolivarian government quells dissent related to environmental injustices through the mechanisms of assimilation (appeasement), violence, and degradation, which refers to the erosion, deterioration and wearing out of livelihood and the bodies of the dwellers in a specific territory so that they can barely survive, much less resist. Meanwhile as the state-led extractivist model is breaking down, a new mining commodity frontier South of the Orinoco river is leading to the entry of militarized and armed groups into these areas and new forms of conflictivity.

Camisani's contribution describes environmental justice conflicts in Sri Lanka, from an analysis of 26 cases of environmental conflict drawing on knowledge from local environmental groups, mainly the Centre for Environmental Justice/Friends of the Earth Sri Lanka. The country's economy is not driven by the exports of primary raw materials. This is in contrast to the Andean countries (analyzed by Perez-Rincon et al. and Teran Mantovani 2017, this feature). The repertoire of contention of environmentalism in Sri Lanka is very much informed by local culture and religion. She describes forms of resistance including 'Dharma Yatra' - a 'peaceful silent pilgrimage' and 'Tree Ordination', which is the practice of recognizing the sacred nature of trees by wrapping them in traditional monks' robes to stop deforestation.

The case report by Da Rocha et al. reflect on their experience developing the FIOCRUZ Brazilian Atlas of Environmental Justice and Health, a precursor and significant source of inspiration for the EJAtlas. This Brazilian atlas (driven for many years by Tania Pacheco and Marcelo Firpo Porto) is mainly focused on health and environmental injustices, with over 600 cases. The authors argue that such inventories and maps serve as important tools to fight injustice and racism, as they increase the visibility of populations whose lives are threatened (Porto et al. 2017). They also point to how sharing of experiences can inspire those who are reticent to engage, turn local struggles into national and international concerns and enable rethinking of strategies and mobilizations based on the cases of success in other contexts.

\section{Single issues in one country: cement kilns in Spain and waste incineration in China}

Herrero and Vilella show how waste is increasingly being used as an alternative to conventional fossil fuels in cement kilns worldwide over the past 20 years, deemed as recycling or waste valorization and supported by big environmental groups and key European institutions. The article aims at characterizing the emerging movement against this practice in Spain and explores its main four discursive dimensions in relation to the concept of environmental justice. They underline the important dimension of justice as putting forward political alternatives: "solutions to co-incineration consist of 
a systemic change of the economy and its dominant culture, particularly in relation to mass production and consumption patterns. This systemic change is captured by the concept of Zero Waste."

Johnson et al. explore the conflictivity around waste incineration in China. Among the eleven conflictive cases already reported in the EJAtlas, they focus on one. They show how this case is notable because it transcended the local arena to raise bigger questions about environmental justice, particularly in relation to public participation in siting decisions, after villagers exposed fraudulent public consultation in the environmental impact assessment. The rural-urban environmental network that emerged out of this conflict is an emblematic example of a new form of organized movement in China that supports "strong sustainability" and can go far beyond environmental issues in challenging multiple forms of domination. Further research based on the EJAtlas could discuss, for example, why in China there are 300 waste incinerators, while in India just an handful, and how many are conflictive, and why (Demaria and Schindler 2015).

\section{Resistance-centered perspective on transformation}

Finally, the article by Temper et al. presents a resistancecentered perspective on transformation, delving deeper into the question of how EJ movements contest and transform different forms of hegemonic power and under what conditions alternatives emerge from conflicts. Drawing from a conflict transformation approach and three grounded initiatives, the authors lay out a conceptual framework for understanding transformations that is multi-dimensional, multi-scalar and intersectional. They contend that radical alternatives are a form of resistance and that, a radical and resistance-centered perspective on transformation, in contrast to a transition approach focused on artifacts and technologies, needs to pay attention to the creation and replication of new subjectivities, power relations, values and institutions.

The collected papers, based on a comparative perspective, shed light on the commonalities and differences of environmentalism across locations, as well as the shape of an incipient global movement for environmental justice, uncovering its potentialities and its prefigurative politics (Martinez-Alier et al. 2016).

\section{Conclusions: contributions to the sustainability science research agenda from a political ecology perspective}

This Special Feature marks the advances of an important line of research integrating ecological economics and political ecology for the study of environmental conflicts worldwide.
The relevance of studying environmental conflicts for better understanding transitions towards sustainable futures has been recognized by two major research grants that support the EJAtlas: the European Research Council (ERC) Advanced Grant "EnvJustice" (2016-2021) and the International Social Science Council sponsored Acknowl-EJ project (2016-2019). Recently a study published in the The Lancet (Landrigan et al. 2017) affirmed that disease caused by pollution is most prevalent among ethnic minorities and the marginalized. The study holds up the EJAtlas as an example of an initiative that aims to investigate, document and map information related to such environmental injustices, pointing out (in the language of the EJ movement in the US of the 1980s) how these initiatives "provide powerful leverage to the disproportionately exposed communities-the poor and the vulnerable-who are struggling to reduce their exposure and their inequitable burden of pollution related disease" (p. 29). If we understand sustainability to imply not only sustainability of the natural environment but healthy lives and communities for all, it is becoming increasingly clear that sustainability initiatives need to more fully address the social inequalities leading to these outcomes. This is what political ecology is all about, and we believe it needs to be placed at the center of sustainability science.

In this line the EJAtlas (and similar initiatives) can open up or reinforce the following research agenda:

\section{Local to global interactions of commodity chains}

Socio-environmental conflicts increase because of the growth and changes in the social metabolism. This process goes together with the insertion of countries and communities into the international economy rather than resulting only from singular patterns of social inequality, what we may call the international division of nature and labor (with origins in the sixteenth century, as we explain here below). The local to global purview of the EJAtlas provides valuable insight into interactions between global processes and local social and ecological conditions. The EjAtlas' socio-metabolic and commodity perspective emphasizes the spatial organization of the economy, elucidating how geographies of injustice touch down in specific locations. Commodities go through different phases, from extraction to transport to manufacture and waste disposal, and conflicts arise in all phases potentially leading to international networks of grassroots environmental justice organizations (as recently shown by Cardoso 2018, for the case of Colombian coal shipped to coal fired power plants in The Netherlands and Turkey, and Temper 2018 for land-grabbing). Such a local to global scale can ultimately contribute to fostering the integration of place-placed research insights into the global sustainability science research and policy agendas (Balvanera et al. 2017). 


\section{Comparative environmentalism in a social movement perspective}

The EJAtlas foregrounds the agency of movements for sustainability. It provides a new tool for understanding the agency of such movements across locations in a historical as well as a comparative perspective, which may shed light on the commonalities and differences of environmentalism across locations, as well as the shape of an incipient global movement for environmental justice, uncovering its potentialities and its prefigurative politics. For example, we may ask about the women leaders in environmental struggles, comparing many cases. We may ask whether environmentalist concerns in some countries are more likely to be expressed in a contentious manner. What is the role of disruptive protest and how does escalation of protest activities lead to differing outcomes? How are different languages of valuation such as livelihood, sacredness, ecological values, territorial rights or economic compensation deployed? How is the technical language of Western environmentalism (increasingly used for strategic reasons) combined with arguments about identity and culture, and to what effect? How do new forms of action appear and are diffused across time and space as for instance popular consultations in South America (Walter and Urkidi 2017)? What are the vocabularies and cultural expressions of the global movement for environmental justice (Martinez-Alier et al. 2014, 2016) such as banners, slogans, documentaries and songs used in the various struggles for environmental justice across the world? These are contributions to a line of study of a perhaps globalizing environmental justice movement (Temper 2017; Martinez-Alier et al. 2016).

\section{Proto-environmentalism}

The oldest conflicts in the atlas currently are the Ashio mine conflict in Japan in 1895 (EJAtlas 2014b) and the Rio Tinto massacre in Huelva, Spain in 1888 (EJAtlas 2018). We may enquire into the question of when did socio-environmental conflicts begin (Temper 2017)? In Potosi because of deaths from the hard working conditions and also from fumes from the amalgam of silver and mercury (Machado 2014)? The international division of nature and labor arose already from the sixteenth century precisely through a racialized coloniality of power and knowledge (Quijano 2000; Grosfoguel 2004) - slavery and other forms of forced labor, world system of unequal colonial trade of only preciosities at the beginning and later bulk commodities, land grabbing by extermination of local population, the new plantations of cotton and sugar that explain much of the industrial revolution (cheap inputs), the destruction of livelihoods (with institutions like the quilombolas and palenques in the Americas escaping already from modernity, capitalism and "economic growth"). While the social actors would however never have used words like "ecology", a historical EJAtlas going back five centuries would certainly be a worthy research endeavor. There is a link to be explored between the booming decoloniality studies (that is essentially a debate over racism) and environmental justice research [that emerged out of claims against ‘environmental racism' (Bullard 1993)].

\section{Unsettling of research methods and politicization of sustainability}

The EJAtlas represents a trans-disciplinary initiative that builds upon the combination of activist and academic knowledge and is co-designed and continually co-created together with advocates, activists, students, citizens, journalists and communities. It is one experiment in integrating activist knowledge into new approaches to knowledge creation that moves beyond the privileging of certified expert perspectives (Temper and del Bene 2016; Martinez-Alier et al. 2011, 2014). Such forms of engaged scholar-activism (Borras 2016) are proliferating and a truly transformative EJ and sustainability research agenda calls for recognition of the epistemologies and ontologies of marginalized voices and for plural knowledges and support for justice movements. We advocate methods for research and practice that integrate new tools for reflexivity, increased experimentation, and due attention to political as well as scientific rigor.

Finally, we put forward that a focus on environmental justice offers the possibility to position environmental questions within a larger critique of unequal social relations and the capitalist globalization process and increasing social metabolism they are embedded in. This special issue argues that the stories of struggle documented in these pages and the EJAtlas can help point towards practicable paths towards equitable and sustainable society-nature relationships. Continued engagement with movement actors can help sustainability science ground its proposals in social and political realities.

Acknowledgements Special thanks to grass-roots activists who continue to be the main source of inspiration, and in particular to all those who have directly or indirectly collaborated and contributed to the EJAtlas. The authors acknowledge the support of the European Research Council for the EnvJustice project (GA 695446) and the International Social Science Council for the ACKnowl-EJ project (TKN150317115354).

\section{References}

Agyeman J (2008) Toward a 'just' sustainability? Continuum 22(6):751-756

Akbulut B, Demaria F, Gerber J-F, Martínez-Alier J (2018) Five theses on the relationships between degrowth and the environmental justice movement. Ecol Econ (forthcoming, submitted) 
Asara V, Otero I, Demaria F, Corbera E (2015) Socially sustainable degrowth as a social-ecological transformation: repoliticizing sustainability. Sustain Sci 10(3):375-384

Avila S (2017) Contesting energy transitions: wind power and conflicts in the Isthmus of Tehuantepec. J Polit Ecol 24:993-1012

Avila S (2018) Environmental justice and the expanding geography of wind power conflicts. Sustain Sci. https://doi.org/10.1007/s1162 5-018-0547-4 (this feature)

Balvanera P, Calderón-Contreras R, Castro AJ, Felipe-Lucia MR, Geijzendorffer IR, Jacobs S, Martín-López B, Arbieu U, Speranza CI, Locatelli B, Harguindeguy NP (2017) Interconnected place-based social-ecological research can inform global sustainability. Curr Opin Environ Sustain 29:1-7

Beck U (1992) Risk society: towards a new modernity. Sage, London Borras SM (2016) Land politics, agrarian movements and scholaractivism. Inaugural lecture. ISS, The Hague

Bullard R (1990) Dumping in Dixie: race, class and environmental quality. Westview, Boulder

Bullard R (1993) Confronting environmental racism. Voices from the Grassroots. South End Press, Boston

Camisani P (2018) Sri Lanka: a political ecology of socio-environmental conflicts and development projects. Sustain Sci (this feature)

Cardoso A (2018) Valuation languages along the coal chain from Colombia to the Netherlands and to Turkey. Ecol Econ 146:44-59

Castells M (1997) The information age, 3 vols. Blackwell, Oxford

da Rocha DF, Porto MF, Pacheco T et al (2017) The map of conflicts related to environmental injustice and health in Brazil. Sustain Sci. https://doi.org/10.1007/s11625-017-0494-5 (this feature)

Del Bene D, Scheidel A, Temper L (2018) More dams, more violence? Analysing global resistances and repression around conflictive dams through co-produced knowledge. Sustain Sci. https://doi. org/10.1007/s11625-018-0558-1 (this feature)

Demaria F (2010) Shipbreaking at Alang-Sosiya (India): an ecological distribution conflict. Ecol Econ 70(2):250-260

Demaria F, D’Alisa G (2013) Dispossession and contamination: strategies for capital accumulation in the waste market. Lo Squaderno 29:37-39

Demaria F, Kothari A (2017) The post-development dictionary agenda: paths to the pluriverse. Third World Q 38(12):2588-2599

Demaria F, Schindler S (2015) Contesting urban metabolism: struggles over waste-to-energy in Delhi, India. Antipode 48(2):293-313

EJAtlas (2014a) The Park is Ours, Banja Luka, Bosnia and Herzegovina. https://EJAtlas.org/conflict/the-park-is-ours-banja-lukabosnia-and-herzegovina. Accessed 2 Feb 2018

EJAtlas (2014b) Ashio Copper Mine, Japan. http://www.EJAtlas.org/ conflict/ashio-copper-mine-japan. Accessed 2 Feb 2018

EJAtlas (2018) The Rio Tinto Company and the massacre of 1888 , Andalusia, Spain. https://EJAtlas.org/conflict/rio-tinto-la-matan za-de- 1888

Georgescu-Roegen N (1971) The entropy law and the economics process. Harvard U.P., Cambridge

Gerber J-F, Scheidel A (2018) In search of substantive economics: comparing today's two major socio-metabolic approaches to the economy-MEFA and MuSIASEM. Ecol Econ 144:186-194

Global Witness (2016) On Dangerous Ground: 2015. deadly environment: the killing and criminalization of land and environmental defenders worldwide. https://www.globalwitness.org/en/campa igns/environmental-activists/dangerous-ground/. Accessed 25 Jan 2018

Grafton B, Colsa Perez A, Hintzen K, Mohai P, Orvis S, Hardin R (2015) From the Michigan Coalition to transnational collaboration: interactive research methods for the future of environmental justice research. Polit Groups Identities 3(4):684-691. https://doi. org/10.1080/21565503.2015.1080622

Grosfoguel R (2004) Race and ethnicity or racialized ethnicities? Identities within global coloniality. Ethnicities 4(3):315-336
Haas W, Krausmann F, Wiedenhofer D, Heinz M (2015) How circular is the global economy?: an assessment of material flows, waste production, and recycling in the European Union and the World in 2005. J Ind Ecol 19(5):765-777

Herrero A, Vilella M (2018) 'We have a right to breathe clean air': the emerging environmental justice movement against waste incineration in cement kilns in Spain. Sustain Sci. https://doi. org/10.1007/s11625-017-0473-x. (this feature)

Johnson T, Lora-Wainwright A, Lu J (2018) The quest for environmental justice in China: the spatial dynamics of citizen opposition to waste incinerators. Sustain Sci. https://doi.org/10.1007/ s11625-018-0545-6 (this feature)

Landrigan PJ, Fuller R, Acosta NJ, Adeyi O, Arnold R, Baldé AB, Bertollini R, Bose-O'Reilly S, Boufford JI, Breysse PN, Chiles $\mathrm{T}$ (2017) The Lancet commission on pollution and health. Lancet 391:10119

Latorre S, Farrell KN, Martinez-Alier J (2015) The commodification of nature and socio-environmental resistance in Ecuador: an inventory of accumulation by dispossession cases, 1980-2013. Ecol Econ 116:58-69

Machado H (2014) Potosí, el origen: genealogía de la minería contemporánea. Mardulce, Buenos Aires

Martinez-Alier J (1995) Distributional issues in ecological economics. Rev Soc Econ 53(4):511-528

Martinez-Alier J (2002) The environmentalism of the poor: a study of ecological conflicts and valuation. Edward Elgar, Cheltenham

Martinez-Alier J, O'Connor M (1996) Ecological and economic distribution conflicts. In: Costanza R, Martinez-Alier J, Segura O (eds) Getting down to earth. Practical applications of ecological economics. Island Press/ISEE, Washington, DC

Martinez-Alier J, Kallis G, Veuthey S, Walter M (2010) Social metabolism, ecological distribution conflicts, and valuation languages. Ecol Econ 70(2):153-158

Martinez-Alier J, Healy H, Temper L, Walter M, Rodriguez-Labajos B, Gerber JF, Conde M (2011) Between science and activism: learning and teaching ecological economics with environmental justice organisations. Local Environ 16(1):17-36

Martinez-Alier J, Anguelovski I, Bond P, Del Bene D, Demaria F, Gerber J-F, Greyl L, Haas W, Healy H, Marín-Burgos V, Ojo G, Porto M, Rijnhout L, Rodríguez-Labajos B, Spangenberg J, Temper L, Warlenius R, Yánez I (2014) Between activism and science: grassroots concepts for sustainability coined by Environmental Justice Organizations. J Polit Ecol 21:19-60

Martinez-Alier J, Temper L, Del Bene D, Scheidel A (2016) Is there a global environmental justice movement? J Peasant Stud 43(3):731-755

Navas G, Mingorría S, Aguilar-Gonzalez B (2018) Violence in environmental conflicts: the need for a multidimensional approach. Sustain Sci. https://doi.org/10.1007/s11625-018-0551-8 (this feature)

Pérez-Rincón M, Vargas-Morales J, Crespo-Marín Z (2017) Trends in social metabolism and environmental conflicts in four Andean countries from 1970 to 2013. Sustain Sci. https://doi. org/10.1007/s11625-017-0510-9 (this feature)

Porto M, Firpo R, Ferreira D, Finamore R (2017) Health as dignity: political ecology, epistemology and challenges to environmental justice movements. J Polit Ecol 24:110-124

Quijano A (2000) Coloniality of power, ethnocentrism, and Latin America. NEPANTLA 1(3):533-580

Scheidel A, Temper L, Demaria F, Martínez-Alier J (2018) Ecological. Ecological distribution conflicts as forces for sustainability: an overview and conceptual framework. Sustain Sci. https://doi. org/10.1007/s11625-017-0519-0. https://doi.org/10.1007/s1162 5-017-0526-1 (this feature) 
Špirić J (2017) Ecological distribution conflicts and sustainability: lessons from the post-socialist European semi-periphery. Sustain Sci. https://doi.org/10.1007/s11625-017-0505-6 (this feature)

Swyngedouw E (2011) Whose environment?: the end of nature, climate change and the process of post-politicization. Ambiente Sociedade 14(2):69-87

Temper L (2017) Globalizing environmental justice Radical and transformative movements past and present. In: Holifield R (eds) Handbook of environmental justice. Jay Chakraborty and Gordon Walker, Routledge

Temper L (2018) From Boomerangs to minefields and catapults: dynamics of trans-local resistance to land-grabs. J Peasant Stud. https://doi.org/10.1080/03066150.2017.1398144

Temper L, Del Bene D (2016) Transforming knowledge creation for environmental and epistemic justice. Curr Opin Environ Sustain 20:41-49

Temper L, Martinez-Alier J (2013) The god of the mountain and Godavarman: net present value, indigenous territorial rights and sacredness in a bauxite mining conflict in India. Ecol Econ 96:79-87

Temper L, Martinez-Alier J (2017) Mapping ecologies of resistance. In: Horowitz LS, Watts MJ (eds) Grassroots environmental governance: community engagements with industrial development. Taylor \& Francis Books, Leiden

Temper L, Del Bene D, Martinez-Alier J (2015) Mapping the frontiers and front lines of global EJ: the EJAtlas. J Polit Ecol 22:255-278
Temper L, Walter M, Rodriguez I, Kothari A, Turhan E (2018) A radical perspective on transformations to sustainability: resistances, movements, alternatives. Sustain Sci. https://doi.org/10.1007/ s11625-018-0543-8 (this feature)

Teran-Mantovani E (2018) Inside and beyond the Petro-State frontiers: geography of environmental conflicts in Venezuela's Bolivarian Revolution. Sustain Sci. https://doi.org/10.1007/s11625-0170520-7 (this feature)

United Church of Christ. Commission for Racial Justice (1987) Toxic wastes and race in the United States: a national report on the racial and socio-economic characteristics of communities with hazardous waste sites. Public Data Access

van der Velden JHA (2007) Strikes around the World, 1968-2005: case-studies of 15 countries. Amsterdam University Press, Amsterdam

Walter M, Urkidi L (2017) Community mining consultations in Latin America (2002-2012): the contested emergence of a hybrid institution for participation. Geoforum 84:265-279

Warner EAK (2015) Working to protect the seventh generation: indigenous peoples as agents of change. Santa Clara J Int Law 13(1):273-291. http://digitalcommons.law.scu.edu/scujil/vol13/ iss $1 / 11$

World Economic Forum (2018) The Global Risks Report 2018. https:// www.weforum.org/reports/the-global-risks-report-2018. Accessed 1 Apr 2018 